\title{
Epibenthic and benthic microcrustaceans (copepods, cladocerans, ostracods) from a nearshore area in southeastern Lake Michigan ${ }^{1}$
}

\author{
Marlene S. Evans and John A. Stewart \\ Great Lakes Research Division, University of Michigan, Ann Arbor 48109
}

\begin{abstract}
Cores of bottom sediments and overlying waters were collected from depths of 6 and $9 \mathrm{~m}$ in southeastern Lake Michigan. Copepod, cladoceran, and ostracod abundances were assessed in terms of known plankton. Species could be roughly divided into euplanktonic species showing no affinity for the sediments, epibenthic species occurring in the plankton but concentrated near the sediments, and benthic species inhabiting the sediments and rarely encountered in the plankton. While several epibenthic species left the sediments at night to enter the plankton, only a small fraction of the benthic species showed this migration. Epibenthic and benthic microcrustaceans in the lower $0.3 \mathrm{~m}$ of the water column accounted for 33-39\% of the standing stock (by numbers) of the microcrustaceans within the $0-\mathrm{m}$ depth contour. Preliminary information on the local food web indicates that the microcrustaceans have a significant role in the trophodynamics of the inshore area. Several of the species found in southeastern Lake Michigan are tolerant of eutrophic, mesotrophic, or moderately saline waters.
\end{abstract}

Although the planktonic crustaceans of the open waters of the Great Lakes have been studied extensively, the epibenthic components have been largely overlooked, probably due to the technical difficulties in collecting from this habitat. Conventional zooplankton sampling gear (nets, water bottles) does not sample the organisms living on the sediments (benthic) or within a few contimetcrs of the scdiments (epibenthic). Sampling gear such as dredges and grabs may collect epibenthic and benthic organisms, but the mesh sizes of screens in these devices and of the sieves used for washing samples are generally coarse $(500 \mu)$ and do not retain the smallest organisms. Where special gear has been used, an abundant and diverse microfauna has been collected (Moore 1939; Cole 1955). Although the trophodynamics of the epibenthic and benthic microfauna have not been well studied in temperate freshwaters, studies in Arctic ponds (Fenchel 1975), brackish waters (Jansson 1974), and marine waters (McIntyre 1964) have shown that microfauna are important in benthic communities both as competitors with the

\footnotetext{
${ }^{1}$ This research was supported by the Indiana \& Michigan Power Company. Great Lakes Research Division contribution 214.
}

macrobenthos for food resources and as prey for benthic invertebrates and fish. In the Great Lakes, microbenthos probably have a similarly significant role.

In summer 1974, we investigated the nearshore arca of southeastern Lake Michigan to determine the specics composition and abundance of the epibenthic and benthic microfauna. The samples contained a diverse assemblage of organisms from a number of taxonomic groups. We here discuss primarily the copepods, cladocerans, and ostracods.

The project was undertaken in cooperation with S. C. Mozley and we acknowledge his advice and help. Divers were J. Dorr and G. Gitschlag.

\section{Materials and methods}

Duplicate sediment cores were collected at five sites 80-100 m apart (Fig. 1) along two transects parallel to shore and extending southward from the intake structures of the Donald C. Cook Nuclear Plant in southeastern Lake Michigan. The plant was not operational in 1974 although water was occasionally drawn from the lake during periods of circulating-pump testing. Transect C (6-m depth contour) was sampled during the afternoon of 22 July 1974, 

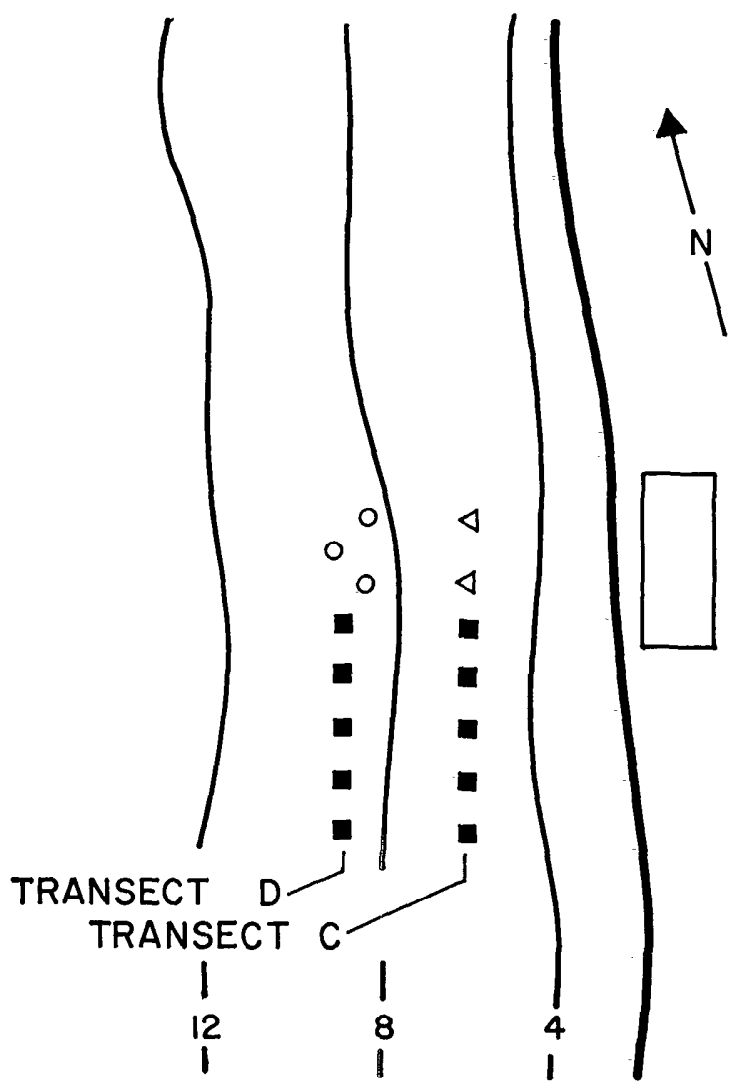

DISCHARGE STRUCTURE

- INTAKE STRUCTURE

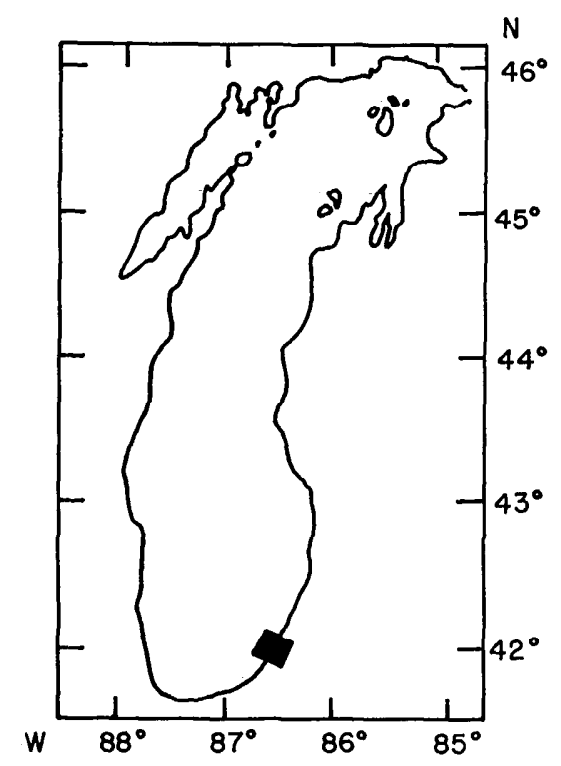

Fig. 1. Location of core sampling sites (22-23 July 1974) for epibenthic and benthic microfauna in southeastern Lake Michigan (insert) and near Donald C. Cook Nuclear Power Plant.

transect $\mathrm{D}$ (9-m depth contour) on the following morning.

Samples were collected by SCUBA divers. A plastic core tube $(46.4 \mathrm{~cm}$ long $\times 7.2$ $\mathrm{cm}$ ID) was pushed into the sediments to a depth of $15 \mathrm{~cm}$, leaving $31.4 \mathrm{~cm}$ of overlying water; thus positioned, the core tube enclosed a sediment surface area of $40.7 \mathrm{~cm}^{2}$ and a water volume of 1.3 liters. The upper portion of the tube was stoppered, the tube removed from the sediments, and then the lower portion of the tube was stoppered. A second core was collected within $3 \mathrm{~m}$ of the first and both brought to the surface. On shore, the contents of each tube were placed in a bucket and the water decanted off and poured through a plankton bucket with a No. 10 mesh $(156 \mu)$ window. The sedi- ment was washed scveral times and the water quickly decanted before suspended organisms had time to settle out. The organisms and a small volume of residual water were then transforred to a labeled jar and preserved with Koechies fluid (a sugar-Formalin solution).

Copepods, cladocerans, and ostracods were counted and identified. Nematoda, Rotifera, Tardigrada, Rhizopoda, and fish eggs were counted but not speciated. Macrobenthic organisms (Insecta, Gastropoda, Amphipoda, Pelecypoda, etc.) were counted and the data given by Mozley (1975). Taxonomy followed Pennak (1963), Deevey and Deevey (1971), and the keys of Wilson, Yeatman, Brooks, and Tressler in Edmondson (1959). Only intact organisms 
wore counted; broken or othcrwise damaged animals were assumed to have been dead at the time of capture.

A grid of stations at an $11-\mathrm{km}$ radius about the Donald C. Cook Nuclear Plant has been surveyed for plankton at monthly intervals from 1970 through the present. Zooplankton compositions vary with station depth, but alongshore currents maintain homogeneity among stations of similar depths. We used these data (not reported here) to evaluate the relative benthic affinities of core crustaceans, since over half of these organisms can also be found in the plankton. As a rough index we show the ratios between mean volumetric densities in the cores and mean volumetric densities in the midsummor plankton of 1974 as measured on two survey dates. On the survey date preceding the core sampling, 11 July, thirtecn stations having depths of 6-9 m were visited; on 22 August six stations within the same depth contours were visited. At each station two replicate hauls were made from about $1 \mathrm{~m}$ above lake bottom to the surface with a 50-cm-diameter net ( $156-\mu$ pore size) equipped with a calibrated flowmeter.

Some epibenthic and benthic microcrustaceans, although rare in the plankton during the day, may entcr the plankton in greater numbers at night. To investigate this, we determined the concentrations of epibenthic and benthic microcrustaceans at midnight and at noon on 4 and 5 August. Zooplankton were collected from nine locations in the intake forebay of the power plant during a period of circulating-pump testing. Water was drawn through a 7.2cm-ID hose by a diaphragm pump and discharged into a 50-cm-diameter plankton nct (156- $\mu$ pore size) suspended in a barrel of water. A regulated outflow pipe at the bottom of the barrel was equipped with a flowmeter, allowing estimates of the volume of water filtered over the sampling period. Over a 2-min period, about $1 \mathrm{~m}^{3}$ of water was filtered. Two 2-min replicates were collected from each location and mean concentrations (of 18 samples) calculated for the various taxa of zooplankton. The intake pipes were located offshore $680 \mathrm{~m}$ (Fig. 1) in $9 \mathrm{~m}$ of water.

\section{Results}

Sediments along transect $\mathrm{C}(6 \mathrm{~m})$ were mostly fine sand, but one sample contained clay lumps and organic matter. Sediments along transect $\mathrm{D}(9 \mathrm{~m})$ were also fine sand but several samples contained silt and organic matter and were gray. The shoreline along the survey area was sandy and dcvoid of rooted aquatic macrophytes.

Our separation of euplanktonic, epibenthic, and benthic microcrustaceans on the basis of the computed ratio of their mean density $\left(\right.$ No. $\mathrm{m}^{-3}$ ) in the 20 cores to their estimated density $\left(\right.$ No. $\left.\mathrm{m}^{-3}\right)$ in the water column is somewhat arbitrary, particularly for the species that were rare in both the core and the plankton samples.

Euplanktonic microcrustaceans are those organisms that live primarily in the plankton and scemingly lack orientation to the sediments. The core : plankton ratios (Table 1) for these taxa in our study were generally 1 or less. An exception is the ratio for Daphnia galeata mendotae, a species associated with open waters of lakes. All of the taxa shown in Table 1 are common in the Great Lakes zooplankton (Watson and Carpenter 1974; Torke 1975). Apart from Bosmina longirostris, which was more abundant at $6 \mathrm{~m}$, the euplanktonic organisms occurred in similar concentrations at 6 and $9 \mathrm{~m}$. Euplankton accounted for $<10 \%$ of the microcrustaccans in the cores taken at $6 \mathrm{~m}$ and $<2 \%$ at $9 \mathrm{~m}$. The mean concentration of these organisms ranged from $4,900 \mathrm{~m}^{-3}$ at $9 \mathrm{~m}$ to $17,400 \mathrm{~m}^{-3}$ at $6 \mathrm{~m}$ and was similar to the estimated zooplankton concentration $\left(14,700 \mathrm{~m}^{-3}\right)$ in the water column.

Epibenthic microcrustaceans are those organisms that commonly occur in the plankton but reach higher concentrations in the waters just above the sediments; they may also live on the sediments. Our computed core : plankton ratios (Table 2) for these taxa ranged from a low of 4 to a high of 1,490. All of the taxa shown in 
Table 1. Mean concentration of euplankton in core samples collected from the 6- and 9-m depth contours in southeastern Lake Michigan on 22-23 July 1974. Ratio for each taxon was calculated by dividing mean concentration (No. $\mathrm{m}^{-2}$ ) in the 20 core samples by estimated concentration (mean of two sampling dates) in overlying water. $\mathrm{SE}$ is standard error of the mean.

\begin{tabular}{|c|c|c|c|}
\hline Taxon & Ratio & $\begin{array}{l}\text { No. } \mathrm{m}^{-3} \\
\times 10^{3} \pm \mathrm{SE}\end{array}$ & $\begin{array}{l}\frac{9 \mathrm{~m}}{\text { No. } \mathrm{m}^{-3}} \\
\times 10^{3} \pm \mathrm{SE}\end{array}$ \\
\hline $\begin{array}{l}\text { Ipopocyctops prasinus } \\
\text { mexicanus }\end{array}$ & 0.1 & 0.0 & $0.2 \pm 0.2$ \\
\hline Diaptomus spp. CI-CV & 1.3 & $2.0 \pm 0.6$ & $2.0 \pm 0.6$ \\
\hline Diaptomus ashlandi cVI & I 1.2 & $0.7 \pm 0.2$ & $1.1+0.3$ \\
\hline $\begin{array}{l}\text { Diaptomus minutus CVI } \\
\text { Iivischura lacustris }\end{array}$ & 0.0 & 0.0 & 0.0 \\
\hline$C I-C V I$ & 0.0 & 0.0 & 0.0 \\
\hline Tota1 copepods & & 2.7 & 3.3 \\
\hline $\begin{array}{l}\text { Bosmina longirostris } \\
\text { Daphnia galeata }\end{array}$ & 1.5 & $14.2 \pm 4.1$ & $1.4 \pm 0.5$ \\
\hline mendotae & 10.0 & $0.1 \pm 0.1$ & 0.0 \\
\hline $\begin{array}{l}\text { Daphnia retrocurva } \\
\text { Ceriodaphrita }\end{array}$ & 0.1 & $0.1 \pm 0.1$ & $0.2 \pm 0.2$ \\
\hline quadrangula & 0.0 & 0.0 & 0.0 \\
\hline Eubosmina coregoni & 0.5 & $0.1 \pm 0.1$ & 0.0 \\
\hline Holopedium gibberum & 0.0 & 0.0 & 0.0 \\
\hline Leptodora kindtii. & 0.0 & 0.0 & 0.0 \\
\hline polyphemus pediculus & 1.8 & $0.2 \pm 0.1$ & 0.0 \\
\hline Tota1 cladocerans & & 14.7 & 1.6 \\
\hline Total euplankton & & 17.4 & 4.9 \\
\hline
\end{tabular}

Table 2 are constituents of Great Lakes zooplankton. Chydorus sphaericus was the only cladoceran that could be considered epibenthic. The group was numerically dominated by the cyclopoid copepods. Immature and adult copepodids were more abundant at $9 \mathrm{~m}$ than at $6 \mathrm{~m}$; these differences werc statistically significant (Student's $t$-test or Mann-Whitney test, $P<$ 0.05) for all taxa other than adult Cyclops vernalis and Eurytemora affinis. Nauplii were significantly more abundant at $6 \mathrm{~m}$. More than half of the corc microcrustaceans were epibenthic forms. The mean concentration of these taxa ranged from 114,000 $\mathrm{m}^{-3}$ at $6 \mathrm{~m}$ to $151,000 \mathrm{~m}^{-3}$ at $9 \mathrm{~m}$.

Benthic microcrustaceans live primarily on or in the sediments; they are exceedingly rare in the plankton. The benthic microcrustaceans (Table 3 ) collected in our core samples were not observed in the summer inshore plankton although they have been collected at other locations and on other
Table 2. Mean concentration of epibenthic microcrustaceans in core samples collected from the 6- and 9-m depth contours on 22-23 July 1974. Ratios calculated as in Table 1. SE is standard error of the mean.

\begin{tabular}{|c|c|c|c|}
\hline & & $6 \mathrm{~m}$ & $9 \mathrm{~m}$ \\
\hline Taxon & Ratio & $\begin{array}{l}\text { No. } 3^{\mathrm{m}^{-3}} \\
\times 10^{2} \pm \mathrm{SE}\end{array}$ & $\begin{array}{l}\text { No. } \mathrm{m}^{-3} \\
\times 10^{3} \leq \mathrm{SE} \\
\end{array}$ \\
\hline Naupli1 & 4 & $17.5 \pm 5.8$ & $4.9 \pm 1.6$ \\
\hline $\begin{array}{l}\text { Cyclopoids CI-CV } \\
\text { Cyclops }\end{array}$ & 24 & $59.8 \pm 12.3$ & $68.6 \pm 8.1$ \\
\hline $\begin{array}{c}\text { bicuspidatus } \\
\text { thomasi CVI } \\
\text { Cyciops vernalis }\end{array}$ & 11 & $3.2 \pm 0.8$ & $9.5 \pm 1.7$ \\
\hline CVI & 1490 & $19.1 \pm 4.9$ & $53.8 \pm 7.7$ \\
\hline $\begin{array}{l}\text { Eurytemora sp. } \\
\text { CI-CV }\end{array}$ & 5 & $1.4 \pm 0.3$ & $4.0 \pm 1.2$ \\
\hline $\begin{array}{l}\text { Furytemora affinis } \\
\text { CVI }\end{array}$ & 670 & $4.9 \pm 1.4$ & $8.5+1.7$ \\
\hline Total copepods & & 105.9 & 149.3 \\
\hline $\begin{array}{l}\text { Chydorus } \\
\text { sphaerious }\end{array}$ & 385 & $7.6 \pm 2.5$ & $1.9 \pm 0.5$ \\
\hline Total epibenthos & & 113.5 & 151.2 \\
\hline
\end{tabular}

dates. The group was numerically dominated by the cladocerans, particularly by Alona affinis, Alona spp., Alonella sp., and Eurycercus lamellatus, all of which were

Table 3. Mean concentration (No. $\mathrm{m}^{-2}$ ) of benthic microcrustaceans collected in core samples from the 6- and 9-m depth contours on 22-23 July 1974 in southeastern Lake Michigan. SE is standard error.

\begin{tabular}{|c|c|c|}
\hline & $6 \mathrm{~m}$ & $9 \mathrm{~m}$ \\
\hline Taxon & $\begin{array}{l}\text { No. } \mathrm{m}^{-2} \\
\times 10^{3}+\mathrm{SE} \\
\end{array}$ & $\begin{array}{l}\text { No. } \mathrm{m}^{-2} \\
\times 10^{3}+\mathrm{SE}\end{array}$ \\
\hline $\begin{array}{l}\text { Hucyclops agilis CVI } \\
\text { Paracyctops fimbriatus }\end{array}$ & $1.9 \pm 0.9$ & $2.8 \pm 0.6$ \\
\hline poppei CVI & $1.0 \quad 10.5$ & 2.810 .2 \\
\hline Canthocamptus sp. CI-CV & $0.01 \pm 0.01$ & $0.2 \div 0.01$ \\
\hline staphylinoides CVI & $0.4 \pm 0.2$ & $0.7+0.3$ \\
\hline Bryocamptus sp. CI-CVI & 0.0 & $0.3 \pm 0.1$ \\
\hline Total Copepods & 3.3 & 6.8 \\
\hline Atona affinis & $3.8 \quad 12.4$ & $7.3+1.8$ \\
\hline Alona spp. & $3.7 \pm 1.1$ & $12.4 \div 2.0$ \\
\hline Alonelia sp. & $0.6+0.2$ & $0.7 ! 0.2$ \\
\hline Burycercus Zamellatus & $4.0+1.2$ & $7.5+1.0$ \\
\hline Ityocryplus sordidus & $0.05 \pm 0.05$ & $1.0: 0.7$ \\
\hline Leydigia quadrangularis & $0.03+0.03$ & 0.310 .3 \\
\hline Tota1 cladocerans & 12.2 & 29.2 \\
\hline Candona sp. & $0.03 \div 0.03$ & $2.9 \pm 2.0$ \\
\hline $\begin{array}{l}\text { Total benthic } \\
\text { microcrustacea }\end{array}$ & 15.5 & 38.9 \\
\hline
\end{tabular}


Table 4. Estimated standing stock (No. $\mathrm{m}^{-2}$ ) of microcrustaceans (copepods, cladocerans, ostracods) in water column at 6- and 9-m depth contours in southeastern Iake Michigan on 22-23 July 1974.

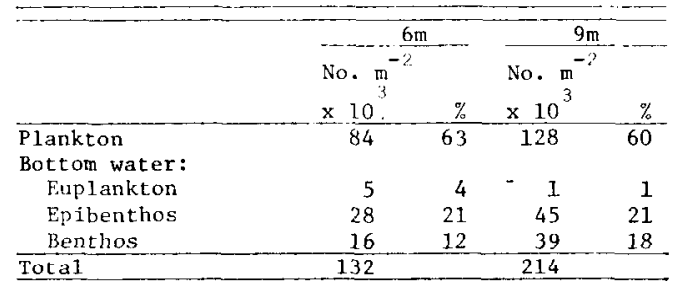

significantly $(P<0.05)$ more abundant at $9 \mathrm{~m}$ than at $6 \mathrm{~m}$. Ostracods, Paracyclops fimbriatus poppei, and Bryocamptus sp. were also significantly $(P<0.05)$ more abundant at $9 \mathrm{~m}$; differences in the concentrations of the remaining taxa were not significant. Benthic microcrustaceans accounted for $28 \%$ of the core microcrustaceans collected at $6 \mathrm{~m}$ and $44 \%$ of the organisms at $9 \mathrm{~m}$. The mean concentration of these taxa ranged from $15,500 \mathrm{~m}^{-2}$ at $6 \mathrm{~m}$ to $38,900 \mathrm{~m}^{-2}$ at $9 \mathrm{~m}$.

In Table 4 , the standing stocks of microcrustaceans in the core samples and in the overlying water are calculated on an areal basis. The areal concentration of total benthic organisms was previously determined (Table 3). We assumed that the lower $0.3 \mathrm{~m}$ contained epibenthic and euplanktonic animals in the densities determined by the core samples and that the portion of the water column above $0.3 \mathrm{~m}$ contained these organisms in the densities estimated from the plankton hauls. Performing the calculations in this manner, we estimate that the lower $3-5 \%$ of the water column contains $37-40 \%$ of the microcrustaceans in the entire water column.

There were higher concentrations of some microcrustaceans in the plankton during the day than during the night (Table 5). Part of this may have been patchiness, but part may have been due to animals living on or near the sediments dispersing into the water column at night. If organisms living in the lower $0.3 \mathrm{~m}$ of water at the $9-\mathrm{m}$ depth contour were dispersed throughout 'lable 5. Mean concentration of epibenthic and benthic copepods, cladocerans, and ostracods collected from intake waters of Donald C. Cook Nuclear Plant at midnight and at noon on $\mathbf{4 - 5}$ Angust 1974. SE is standard error.

\begin{tabular}{|c|c|c|}
\hline Taxon & $\begin{array}{l}\text { Mistuipht } \\
\text { No. } m^{-1} \text { SE }\end{array}$ & Nom $m^{-!} \cdot S E$ \\
\hline $\begin{array}{l}\text { Naupl i i } \\
\text { : in mopliatus }\end{array}$ & $626 \cdot 148$ & $1.1113 \cdot 358$ \\
\hline $\begin{array}{c}\text { thind CI-CV } \\
\because+2 \text { andidatus }\end{array}$ & $2,177+254$ & $1.893+254$ \\
\hline thiniss CVI & $749+106$ & $419 \cdot 62$ \\
\hline 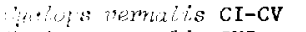 & $851+133$ & 322,76 \\
\hline$\because$ ano vernalis CVI & $309+37$ & $27 \cdot 3$ \\
\hline Erorem temra sp. CI-CV & $1,822+253$ & $1,035+162$ \\
\hline Wiratem affinis CVI & $812+93$ & 65,15 \\
\hline 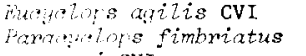 & $1+1$ & 111 \\
\hline (1) CVI & 0 & 0 \\
\hline 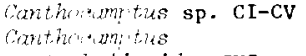 & 0 & $2+$ \\
\hline 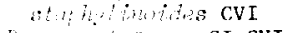 & 0 & 0 \\
\hline$B_{1} \cdot w_{i}$ tus sp. CI-CVI & 0 & 0 \\
\hline$A \& x_{i}$ spp. & $44+19$ & 0 \\
\hline$A T C p_{i}+\therefore i \mathrm{sp}$ & 0 & 0 \\
\hline 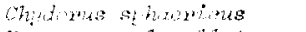 & $187 \div 41$ & 14 \\
\hline Wurneryeng ?onellatus & $15: 4$ & 0 \\
\hline Ilyourytus sordidus & 1) & 0) \\
\hline 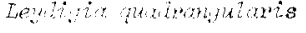 & 0 & 0 \\
\hline Exyzkngt sp. & 0 & 9 \\
\hline
\end{tabular}

the water column at night, they would be reduced to about 0.03 of their daytime concentration at the 9-m contour and their concentration in the night plankton would increase. The actual increase would be dependent on the core : plankton ratio. For a ratio of 1 , the increase would be a factor of 0.03 and would be undetectable; for a ratio of 1,000 , the increase would be a factor of 30 which would be detectable.

Some of the epibenthic organisms appear to leave the sediments at night. Chydorus sphaericus and adult $C$. vernalis and $E$. affinis were 11 to 13 times more abundant in the night plankton collections than in the day collections. Had the entire populations of these microcrustaceans left the bottom at night, increases in the plankton would have been by factors of 45,20 , and 12 for the three species. The actual values suggested that $25 \%$ of the $C$. vernalis, $60 \%$ of the $E$. affinis, and most or all of the C. sphaericus entered the night plankton. Immature $C$. vernalis, Cyclops bicuspidatus thomasi, and E. affinis, as well as adult C. bicuspidatus 
thomasi, were 1.2 to 2.6 times more abundant in the night plankton than in the day plankton. The core: plankton ratios for these taxa were small $(<24)$. If all the copepods living near the sediments cntered the plankton, this would have amounted to a nighttime concentration about double the concentrations of these organisms in the day plankton; such values were observed.

Although benthic copepods, cladocerans, and ostracods have been collected in the open waters of the Great Lakes, the numbers have always becn low, even at night. Eurycercus lamellatus and Alona spp. were collected only at night in the intake waters of the power plant (Table 5). About 1544 animals were collected per cubic meter of water, corresponding to an areal concentration of $135-396 \mathrm{~m}^{-2}$ at the $9-\mathrm{m}$ depth contour. These values were considerably lower than the concentrations indicated in Table 3 and suggest that $<2 \%$ of the populations of these two genera enter the plankton at night. Other taxa such as Eucyclops agilis and $P$. fimbriatus poppei were absent or undetectable $\left(<1 \mathrm{~m}^{-3}\right)$ in the night plankton although they were abundant in the core samples at $9 \mathrm{~m}\left(2,800 \mathrm{~m}^{-2}\right)$; hence fewer than $0.4 \%$ of these organisms appeared to have left the sediments at night.

Among the adult copepods, females generally outnumbered the males. Egg sacs were carried by females of all species except the harpacticoid Canthocamptus staphylinoides. Some of the large numbers of nauplii and immature cyclopoids in the core samples may have been progeny of these species. About $22 \%$ of the adult population of C. staphylinoides were encysted. Although $C$. bicuspidatus thomasi has been observed in cysts in other lakes during summer (Moore 1939; Cole 1955), we did not find it in cysts.

Other microfaunal taxa in the cores were nematodes $\left(58,000 \mathrm{~m}^{-2}\right)$, rotifers $(4,300$ $\left.\mathrm{m}^{-3}\right)$, and rhizopods and tardigrades $(<50$ $\left.\mathrm{m}^{-2}\right)$. Estimates of abundance are minima since these organisms can usually escape through a $156-\mu$ mesh. The bottom con- taincd an average of 1,000 fish eggs per square meter.

\section{Discussion}

In summer, the microcrustaceans (copepods, cladocerans, ostracods) living on the sediments and in the overlying water are numerous and diverse. Epibenthic and benthic taxa in the lower $0.3 \mathrm{~m}$ of the water column and sediments were found in mean concentrations of $44,000 \mathrm{~m}^{-2}$ at $6 \mathrm{~m}$ and $84,300 \mathrm{~m}^{-2}$ at $9 \mathrm{~m}$. Macrobenthos (excluding the nematodes) wore found in concentrations of $21,700 \mathrm{~m}^{-2}$ at $6 \mathrm{~m}$ and $42,000 \mathrm{~m}^{-2}$ at $9 \mathrm{~m}$ (Mozley 1975); if the nematodes are included, these figures become $79,700 \mathrm{~m}^{-2}$ and $100,000 \mathrm{~m}^{-2}$. Therefore, the standing stock of epibenthic and benthic copepods, cladocerans, and ostracods approaches that of the macrobenthos on a numerical basis although not on a biomass basis. In summer, when copepod, cladoceran, and ostracod generation times are short, these microcrustaceans would play an important role in the trophodynamics of the nearshore area.

The microcrustaceans consist of ooze browsers such as Ilyocryptus, Canthocamptus, and Canclona and seston feeders such as Chydorus and Eurycercus (Lindeman 1941; Frey 1971). Carnivores include $C$. vernalis and C. bicuspidatus thomasi (McQueen 1969; Anderson 1970). Predators on the microcrustaceans include some species of Turbellaria and Naididae. The naidid Chaelogaster diaphanus was observed with large numbers of $C$. bicuspidatus thomasi and C. vernalis in its guts; occasional C. sphaericus, B. longirostris, and Alona spp., were also present. Microcrustaceans have been seen in the guts of several species of turbellarians (Mozley pers. comm.). Some species of nematodes may also be carnivorous (Wetzel 1975). Spottail shiners, yellow perch, trout perch, and smelt feed along the bottom; during early life stages, they prey heavily on copepods and cladocerans. Alewives remain planktivorous throughout their lives, consuming euplanktonic and epibenthic forms. Benthic animals such as Eurycercus are also 
consumed (Gannon 1972), possibly when they enter the water column at night.

Microcrustaceans were more abundant at $9 \mathrm{~m}$ than at $6 \mathrm{~m}$ and were generally most numerous in cores containing the highest numbers of macroinvertebrates. These differences are more readily explained in terms of distribution of food than of predation. In the absence of rooted vegetation along the shoreline, the benthic community must depend on the settling out of detritus from the water column and on benthic algal production, both of which depend in turn on stability of the lake bottom. Progressively deeper regions of the nearshore area are progressively less susceptible to disturbance by waves and currents and so accumulate more detritus and algae. On the lake bottom in summer, detrital patches were scarce in waters shallower than $9 \mathrm{~m}$ but more abundant in deeper waters (Ayers and Seibel 1973). Divers observed no silt patches at any of the collection sites of transect $\mathrm{C}$ but several along transect $\mathrm{D}$ (Dorr and Miller 1975).

Several of the epibenthic and benthic microcrustaceans that we found attain maximum concentrations in the eutrophic and mesotrophic regions of the Great Lakes, including A. affinis, C. sphaericus, E. lamellatus, and C. vernalis (Patalas 1972; Gannon 1972; Watson and Carpenter 1974). The last two spccies were not observed in Lake Michigan before 1954 (Wells 1960) but since then have been commonly collected in the plankton; however they are abundant only in the shallow, eutrophic areas of the lake. Eurytemora affinis, a brackish-water calanoid was first detected in Lake Erie in 1961 (Engel 1962) and is now found in Lakes Ontario, Huron, and Michigan. Although E. agilis, C. vernalis, and $C$. bicuspidatus thomasi occur in a wide variety of freshwater habitats (Anderson 1974), they are also able to survive in slightly $(<1 \%$ ) to moderately saline $(<10 \%$ ) waters (Whittaker and Fairbanks 1958). Paracyclops fimbratus, a species rarely reported, was collected from a slightly saline lake in the Columbia basin by Whittaker and Fairbanks (1958).
Many changes in the biota of Lake Michigan have been documented since the early 1900s and are believed to be associated with the increased eutrophication of the lake (Becton 1969). It is possible that with increased eutrophication many pollutiontolerant epibenthic copepods and cladocerans that are presently abundant near the sediments may become increasingly more common in the plankton and displace less tolerant species. The epibenthic and benthic components of the nearshore aquatic community not only are significant components of the food web but may become useful as indicators of changes in the environmental quality of the nearshore area of the lake.

\section{References}

ANDERson, R. S. 1970 . Predator-prey relationships and predation rates for crustacean zooplankters from some lakes in western Canada. Can. J. Zool. 48: 1229-1240.

. 1974. Crustacean plankton communities of 340 lakes and ponds in and near the National Parks of the Canadian Rocky Mountains. J. Fish. Res. Board Can. 31: 855-869.

Ayers, J. C., AND E. Seiber. 1973. Study of aquatic macrophytes. Benton Harbor Power Plant Limnol. Stud. Part 13, p. 169-177. Cook Plant Preoper. Stud., 1972. Univ. Mich., Great Lakes Res. Div. Spec. Rep. 44.

BeEton, A. M. 1969. Changes in the environment and biota of the Great Lakes, p. 150187. In Eutrophication: Causes, consequences, correctives. Natl. Acad. Sci. Publ. 1700.

Cole, G. A. 1955. An ecological study of the microbenthic fauna of two Minnesota lakes. Am. Midl. Nat. 53: 213-230.

Deevey, E. S., And G. B. Deevey, 1971. The American species of Eubosmina Seligo (Crustacea, Cladoccra). Limnol. Oceanogr. 16: 201-208.

Dorr, J. A. III, AND T. J. Miller. 1975. Underwater observations in southeastern Lake Michigan near the Donald C. Cook Nuclear Plant. Benton Harbor Power Plant Limnol. Stud. Part 22. 32 p. Univ. Mich., Great Lakes Res. Div. Spec. Rop. 44.

Edmondson, W. T. [ed.] 1959. Fresh-water biology, 2nd ed. Wiley.

ENGEL, R. 1962. Eurytemora affinis, a calanoid copepod new to Lake Erie. Ohio J. Sci. 62 : 252.

Fenchel, T. 1975. The quantitative importance 
of the benthic microfauna of an Arctic tundra pond. Hydrobiologia 46: 445-464.

Frey, D. G. 1971. Worldwide distribution and ecology of Eurycercus and Saycia (Cladocera). Limnol. Oceanogr. 16: 254-308.

Gannon, J. 1972. A contribution to the ecology of zooplankton Crustacea of Lake Michigan and Green Bay. Ph.D. thesis, Univ. Wisconsin-Milwaukee. 257 p.

JAnsson, A. M. 1974. Community structure modelling, and simulation of the Cladophora ccosystem in the Baltic Sea. Contrib. Asko Lab. (Univ. Stockholm) 5. $130 \mathrm{p}$.

LINDEMAN, R. L. 1941. Seasonal food-cycle dynamics in a senescent lake. Am. Midl. Nat. 26: 636-673.

MCInTYRe, A. D. 1964. Meiobenthos of sublittoral muds. J. Mar. Biol. Assoc. U.K. 44: 665-674.

McQueEn, D. J. 1969. Reduction of zooplankton standing stock by predaceous Cyclops bicuspidatus thomasi in Marion Lake, British Columbia. J. Fish. Res. Bd. Can. 26: 16051618.

Moore, G. II. 1939. A limnological investigation of the microscopic benthic fauna of Douglas Lake, Michigan. Ecol. Monogr. 9: 537-582.

MozLey, S. C. 1975 . Preoperational investigations of zoobenthos in southeastern Lake Michigan near the Cook Nuclear Plant.
Univ. Mich., Great Lakes Res. Div. Spec. Rep. 56. $132 \mathrm{p}$.

Patalas, K. 1972. Crustacean plankton and the eutrophication of the St. Lawrence Great Lakes. J. Fish. Res. Bd. Can. 29: 14511462.

Pennak, R. W. 1963. Species identification of the freshwater cyclopoid Copepoda of the United States. Trans. Am. Microsc. Soc. 82: 353359.

Torke, B. 1975. The population dynamics and life histories of crustacean zooplankton at a deep-water station in Lake Michigan. Ph.D. thesis, Univ. Wisconsin-Milwaukee. $91 \mathrm{p}$.

Watson, N. H., and G. F. Carpenter. 1974. Seasonal abundance of crustacean zooplankton and net plankton biomass of Lakes Huron, Eric and Ontario. J. Fish. Res. Bd. Can. 31 : 309-317.

Wells, L. 1960. Seasonal abundance and vertical movements of planktonic Crustacea in Lake Michigan. Fish. Bull. 60: 343-369.

Wetzel, R. G. 1975 . Limnology. Saunders.

Whittaker, R. HI., and C. W. Fairbanks. 1958. A study of plankton copepod communities in the Columbia Basin, southeastern Washington. Ecology 39: 46-65.

Submitted: 1 November 1976 Accepted: 28 March 1977 